\title{
Protecting aircrew from cold stress elevates heat stress
}

\author{
Andrew P Hunt \\ From 15th International Conference on Environmental Ergonomics (ICEE XV) \\ Portsmouth, UK. 28 June - 3 July 2015
}

\begin{abstract}
Introduction
Aircrew need to wear an immersion suit to protect against hypothermia in the unlikely event of crashing into cold water. These clothing configurations provide insulation and water tight seals to reduce body heat loss in water; however, heat loss will also be impaired during normal flying activities in a warm cockpit. Therefore, this study evaluated the heat exchange properties of the Aircrew Protective Clothing Configuration (APCC) to determine the limitations it may impose to work in warm environments.
\end{abstract}

\section{Methods}

The heat exchange properties of six APCC's were measured on a heated sweating manikin (Newton P-352, MTNW, USA) in accordance with standard test procedures $[1,2]$. Outer garments included a standard flying suit (FLY) and a Constant Wear Immersion Suit (CWIS). Three combinations of undergarments were evaluated with each outer garment. The Method for Evaluating Thermal Strain (METHS) model was used to estimate the heat strain of wearing the APCC's. The work scenario included a 20 min pre-flight period of moderate work $(350 \mathrm{~W})$ and a flight period of up to 4 hours of light work $(150 \mathrm{~W})$. The work duration until core body temperature rose from $37.0{ }^{\circ} \mathrm{C}$ to $38.5{ }^{\circ} \mathrm{C}$ was examined across a range of Wet-Bulb Globe Temperature (WBGT) including: 23.6, 26.4, 26.9, 28.5, 29.5, 29.7, $31.1,32.5,33.0$, and $36.5^{\circ} \mathrm{C}$.

\section{Results}

Additional undergarments increased the thermal resistance of the FLY and CWIS configurations (FLY-1: 0.234; FLY-2: 0.269, and FLY-3: 0.320; CWIS-1: 0.273;

Correspondence: andrew.hunt2@dsto.defence.gov.au

Land Division, Defence Science and Technology Organisation, Melbourne, Australia 
a negligible effect on work duration, which was highly restricted irrespective of the clothing worn.

\section{Conclusion}

The decision to don immersion protective clothing to protect against hypothermia in the event of a crash into cold water must be balanced with the risk of elevated heat strain during flight.

Published: 14 September 2015

\section{References}

1. American Society for Testing and Materials: Standard Test Method for Measuring Thermal Insulation of Clothing Using a Heated Manikin. ASTM 2010, F1291-10.

2. American Society for Testing and Materials: Standard Test Method for Measuring the Evaporative Resistance of Clothing Using a Sweating Manikin. ASTM 2010, F2370-10.

doi:10.1186/2046-7648-4-S1-A18

Cite this article as: Hunt: Protecting aircrew from cold stress elevates heat stress. Extreme Physiology \& Medicine 2015 4(Suppl 1):A18.

Submit your next manuscript to BioMed Central and take full advantage of:

- Convenient online submission

- Thorough peer review

- No space constraints or color figure charges

- Immediate publication on acceptance

- Inclusion in PubMed, CAS, Scopus and Google Scholar

- Research which is freely available for redistribution

Submit your manuscript at www.biomedcentral.com/submit 